\title{
Honrar a vida e o mundo em palcos de afecto
}

\section{Maria João Brilhante}

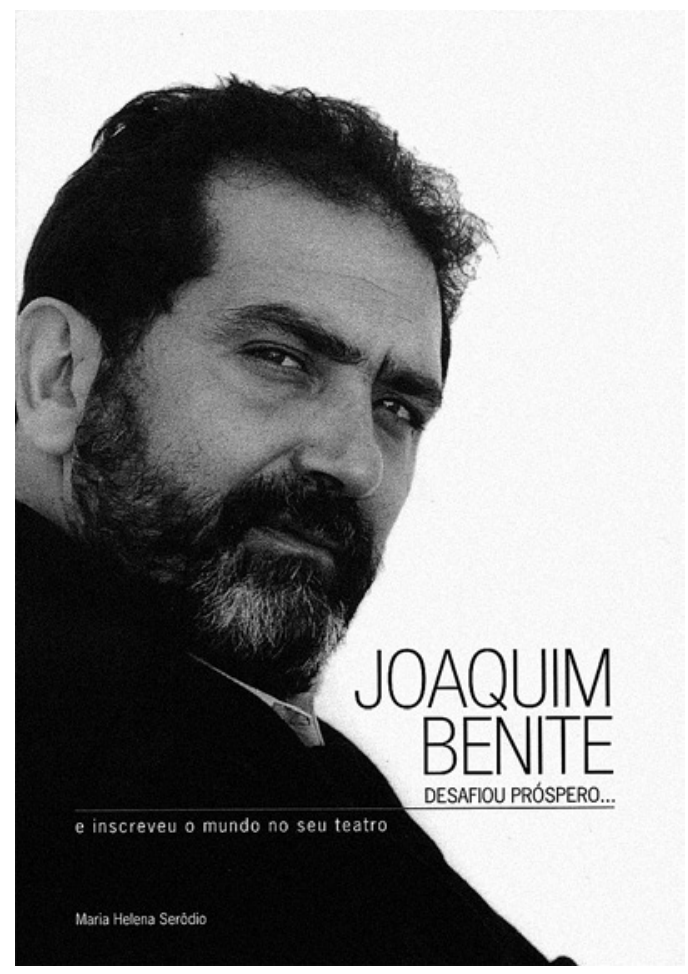

Maria Helena Serôdio, Joaquim Benite: Desafiou Próspero... e inscreveu o mundo no seu teatro, Almada, Companhia de Teatro de Almada, 2013, 372 pp.

A intensa e variada actividade daquele invulgar fazedor de teatro que foi Joaquim Benite, cujo falecimento em finais de 2012 tem de facto deixado mais pobre a cena portuguesa, é justa e oportunamente repercorrida no belo livro produzido em tempo recorde por Maria Selena Serôdio, que nos guia na reconstrução duma vida feita de paixão e militância evocada nas imagens, nas palavras, nos espectáculos, nas acções que se materializaram numa revista, num Festival, em publicações, e que a sua ausência não conseguirá apagar.

Ao folhear-se este livro destacam-se desde logo as suas principais qualidades: apuro gráfico, relevância da informação coligida, pertinência da estrutura (bipartida em texto sobre Joaquim Benite e textos de Joaquim Benite), exposição inteligente dos dados (para onde somos permanentemente remetidos) e discreta, subtil e perspicaz interpretação de toda a documentação disponivel. 0 apuro gráfico torna agradável o manuseio e convida à leitura, evidenciando o bom trabalho de selecção e inserção das imagens que na justa medida vão acompanhando momentos marcantes do percurso de Joaquim Benite, artista e cidadão. Mas a dimensão, o tipo de papel, os separadores coloridos, a segmentação do texto pelas páginas ritmando a leitura, bem como a disposição elegante e eficaz dos títulos e subtítulos, são outros aspectos que merecem o olhar atento do leitor.

A importância e exaustividade da informação coligida deve-se como seria de esperar à autora que, como sobejamente comprovado pelo seu currículo académico, possui larga experiência na recolha, tratamento e estudo de documentação teatral. Fica bem patente, por exemplo, na excelente utilização dos testemunhos escritos dos críticos que acompanharam por vários anos o trabalho de Benite, textos que a autora sujeita a cruzamentos e confrontos e que modaliza na sua relação com o contexto de trabalho da Companhia de Teatro de Almada e até com as circunstâncias sociais e políticas que ajudam o leitor a reconhecer o impacto que essas circunstâncias têm na criação e na vida dos artistas. 0 leitor reconstitui deste modo uma pluralidade de vozes em variados registos (entusiasticos, concordantes, discordantes...) que revelam a ressonância pública do debate em torno do teatro mesmo em tempos de restrição da liberdade de expressão. Mas também os textos escritos por Joaquim Benite são sujeitos a leitura fina, só possivel a quem domina completamente mais de quatro décadas de teatro, não só feito em Portugal.

A estrutura do livro é pertinente porque na 1a parte o texto não segue a sucessão cronológica dos dados, propõe antes sete perspectivas que correspondem a uma particular interpretação do perfil humano, artístico e de cidadão de Joaquim Benite.

Uma dessas perspectivas consiste no papel que as pessoas tiveram na vida de Benite, a começar por aquelas com que se cruzou na sua actividade de jornalista e a que se foram juntando muitas outras, em Portugal e por outras paragens onde andou já com o teatro como centro da sua vida. Uma rede de afectos e de solidariedade que teve o talento de construir e que explicam em parte a fidelidade dos públicos à Companhia e ao Festival Internacional de Teatro de Almada, mas também o respeito que por ele tinham os seus pares.

Em seguida, a aprendizagem como motor contínuo da sua acção no teatro ou fora dele, que Maria Helena 
Timão de Atenas,

de William Shakespeare,

enc. Joaquim Benite

Companhia de Teatro de

Almada, 2012

(Paulo Matos,

Luis Vicente),

fot. Rui Carlos Mateus.
Serôdio consegue evidenciar com mestria, seguramente o fio mais surpreendente que se retira da leitura dos seus textos, mas também das opções dramatúrgicas e artísticas do seu trabalho de encenador ou do discurso programático acerca da companhia.

Depois, aquilo a que Maria Helena Serôdio chamou "os itinerários plurais", ou seja, a criação de um trilho que nasce em 1970, em Campolide, bairro de trabalhadores, com o Grupo de Teatro de Campolide e a experiência de trabalho com amadores, momento também das primeiras experimentações artisticas, trilho que continua depois de 1977 já com estatuto profissional e um emblemático espectáculo (1383, com texto de Virgílio Martinho), para prosseguir em Almada com a renomeada Companhia de Teatro de Almada. Etapas de um crescimento artístico ponderado e da afirmação inequívoca do compromisso com aqueles que justificam o trabalho da companhia: os espectadores.

Maria Helena Serôdio destaca ainda as relações electivas que Joaquim Benite foi construindo com os que atraía para o trabalho na companhia, com instituições como a Câmara Municipal de Almada, com associações e grupos locais, com escolas como a D. António da Costa e com outros profissionais de teatro, escritores, críticos, jornalistas. Relações que acabavam por partilhar a sua paixão pelo teatro e pela sua companhia.

Quando Maria Helena Serôdio passa à análise do reportório, seguramente a perspectiva privilegiada nesta obra por ser a criação de espectáculos o núcleo da actividade de Joaquim Benite, surgem perante nós com clareza pelo menos três grandes linhas orientadoras duma firme direcção artística: o interesse por autores contemporâneos portugueses mais ou menos jovens, a escolha de autores estrangeiros que transmitiam uma visão do mundo próxima da sua, e os clássicos, os grandes textos onde encontrava a sabedoria universal sobre a humanidade. Linhas que se complexificavam através de certas escolhas temáticas como a dramturgia de temática feminista por exemplo, bem identificada por Maria Helena Serôdio -, em que se reconhece o mesmo gesto militante de dar a conhecer, de alargar o pensamento crítico, de estabelecer o fundamental vínculo entre a companhia e o seu ou seus públicos. Maria Helena Serôdio vai referindo espectáculos memoráveis que a recepção crítica tornou imortais, apontando razões para o seu sucesso e traçando, através desses e de muitos outros, a identidade da companhia e a persistente prossecução de um programa artístico e cívico onde se reconhecia a assinatura de Joaquim Benite.

Um capitulo sobre o Festival Internacional de Teatro de Almada revela o que muitos sabemos: a persistência

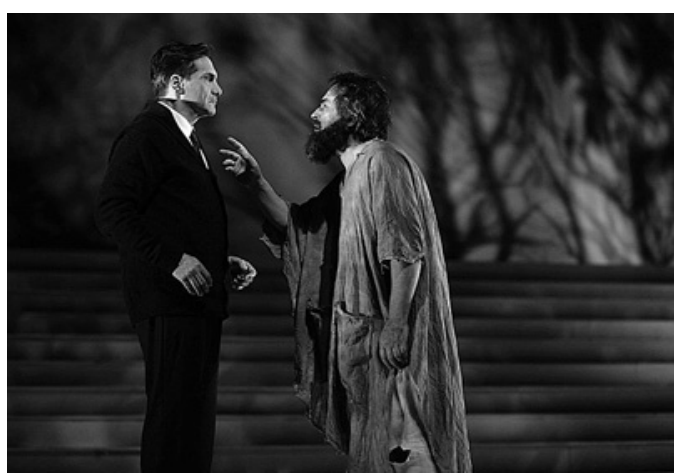

com que o produziu ano após ano, gerindo as dificuldades e parecendo até afrontá-las com um orgulho desafiante. Graças ao Festival temos oportunidade para reencontrar amigos, rever ou ver espectáculos perdidos no Inverno, descobrir artistas e criações surpreendentes ou já afamadas e tudo isto, num ambiente descontraído e informal.

Por fim, surge o Joaquim Benite crítico de teatro, atento ao novo, consequente na defesa da sua ideia de teatro interventivo ou questionador da realidade social e política. Segundo Maria Helena Serôdio, esta prática justifica a importância que continuou a atribuir à análise e à reflexão escritas, concretizadas, por exemplo, nos materiais que a Companhia disponibilizava ao público para estimular o gesto de avaliação dos espectáculos, que considerava indispensável. Essa atenção às letras, estava presente na eleição do texto como ponto de partida do espectáculo e no rigor e demora que colocava na leitura dramatúrgica, mas Maria Helena Serôdio evoca estes aspectos para falar de uma "partitura muito própria" resultante de um método que visava "uma relação viva com o público" e que acabou por constituir uma poética de cena.

Assim se organiza, em traços largos, a $1^{\text {a }}$ parte do livro. Nela somos levados a compreender a acção de Benite através de 43 anos de trabalho à frente da sua companhia de teatro, pondo em prática ou experimentando ideias, desdobrando-se nas funções de director artístico, encenador e gestor, mas sempre mantendo e reforçando os vínculos com a sociedade, num diálogo permanente com o público, com as pessoas que eram a maior motivação para a construção das temporadas, para as suas opções artísticas, para os convites a outros artistas e para a defesa do teatro, em ditadura ou em democracia.

0 livro tem uma $2^{\text {a }}$ parte que nos permite aceder em directo à escrita tão pessoal de Joaquim Benite, sempre virada para o mundo e a partir de certo momento para o mundo no teatro, tudo em registo franco, pontuado por humor nuns casos, sarcasmo noutros: uma oportunidade única para conhecermos textos dispersos que compreendemos talvez melhor depois do inteligente e rigoroso exercicio de exegese feito por Maria Helena Serôdio.

Enfim, trata-se de um precioso objecto que junta ao rigor da pesquisa documental a contextualização histórica política e artística, tão necessária aos leitores mais jovens. É, sobretudo, uma revisitação solidária e afectuosa das etapas de uma vida vivida com e para o teatro, realizada por uma estudiosa e espectadora atenta de um percurso artístico marcante na história do nosso teatro. 


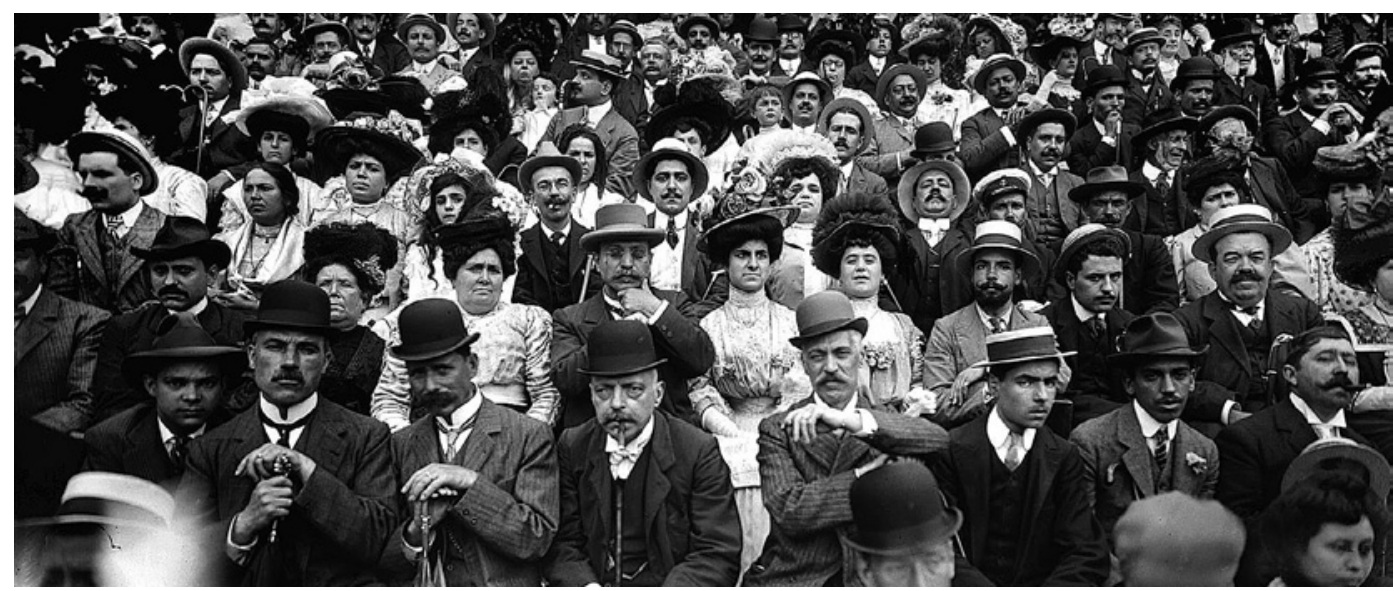

\section{O Bairro Teatral Portuense}

\section{Daniel Rosa}

As responsabilidades de um estágio no actual Teatro Nacional S. João trouxeram consigo o que parecia ser um moroso levantamento de toda a actividade daquela casa de espectáculos e do Teatro Carlos Alberto, desde a inauguração deste último, em finais do século XIX, até meados da centúria seguinte. Tal empresa só seria suavizada por um estudo histórico-artístico sobre o Teatro Carlos Alberto, que o estado da arte parecia necessitar. Contudo, dei por finalizado o estágio não com um sentimento de dever cumprido, por haver preenchido uma lacuna na historiografia da cidade que era a minha então, mas com uma sensação de que havia aberto vários buracos, sentindo-me agora responsável por eles. Se ao principio era um teatro, rapidamente passaram a dois ou três e, de repente, toda a cidade parecia reclamar a atenção dos investigadores.

No entanto, vasculhando por entre livros e arquivos pouco encontrei. Onde podia ler sobre a história dos teatros portuenses? É certo que havia interessantes aportes sobre a história arquitectónica de alguns teatros oitocentistas, mas que contavam eles sobre a vivência destes edifícios que, na sua maioria, haviam chegado aos nossos dias? Claro que havia vários relatos da época, mas, à medida que examinava a bibliografia sobre o assunto, todos se resumiam a episódios que eram contados uma e outra vez, uns de forma objectiva e outros com mais floreado, mas sempre com o mesmo conteúdo. Sabia-se que Camilo (Castelo Branco) havia incendiado (no sentido metafórico!) o Teatro de S. João, que os irmãos Rosa faziam sucesso na época, que fora Ciriaco o último empresário a explorar o malogrado Teatro Baquet. Sabia-se o que Sousa Bastos contava, em meia dúzia de linhas do seu dicionário, sobre as companhias e os artistas que decidira imortalizar. Todas estas inquietações faziam-se sentir vertiginosamente enquanto elaborava o vasto e pormenorizado levantamento sobre a actividade dos dois teatros.

Começando em 1897, lia todos os dias páginas do Comércio do Porto e do Primeiro de Janeiro - os principais diários da época - ano a ano. À medida que avançava ia constatando, com alguma surpresa, a frenética boémia cultural que se vivia entre finais de oitocentos e inícios de novecentos no centro da cidade. Mais: quando dava o meu dia por terminado na Biblioteca de S. Lázaro, no Porto, ali para os lados do Campo 24 de Agosto, deixavame desaguar, num passeio moroso, até à Avenida dos Aliados. Passando pela Praça da Batalha, Rua de Santa Catarina, 31 de Janeiro, Sá da Bandeira ou Passos Manuel, perguntava-me o que havia acontecido para se ter instalado tal dormência cultural no meu Porto contemporâneo. No de então, e por essas mesmas artérias que percorria, havia toda uma circulação de pessoas em busca de divertimento, por entre cafés, teatros e cinemas que não tinham mãos a medir para tanta procura. Mais do que ler, via e sentia isso nos relatos dos periódicos: das suas letras nasciam imagens, como naqueles filmes de animação onde começam a saltar personagens, cores e odores dos livros. Que havia acontecido à agora soturna Praça da Batalha? 0 Teatro de S. João ali continuava, ainda que sem a mística de outros tempos, porém já com o estatuto de Nacional, como o lisboeta D. Maria II. Mas e o devoluto Cine Águia d'Ouro? Antes disso fora teatro e, pelo que se contava na imprensa da época, parecia ter sido bastante importante na sociabilidade da vida portuense. Mas onde podia ler sobre isso? E o Cinema Batalha, o gigante adormecido e agora uma ruína? Dizia-se que tivera um humilde antepassado, tal como as igrejas tinham, no passado, a sua ermida, ainda na minha forma de pensar de historiador de arte mais entendido na vertente religiosa.

Ponderando, entre rabiscos que ia fazendo pelo sim pelo não no meu diário de bordo, achei que tinha um achado em mãos. Era o meu filão, o meu bloco de mármore em bruto - estudar não só um teatro, mas a história de todos eles. Por isso, e quando a seu devido tempo chegou a altura da escolha do tema da dissertação de doutoramento, decidi chamar-Ihe: "Para a história dos teatros do Porto dos séculos XIX-XX". Era um título feio e impreciso, mas temporário. Havia agora, tal como aquele que seria o objecto de estudo, que lapidá-lo pois ainda nos finais do estágio, e já com o estudo sobre a vivência e ambiência do Teatro Carlos Alberto feito, começou a tornar-se curioso, à medida que cruzava as datas de inauguração dos vários teatros que achava carentes de cuidados historiográficos intensivos, a forma como se
Daniel Rosa

é licenciado em História da Arte pela Faculdade de Letras da

Universidade do Porto, foi bolseiro da

Fundação para a

Ciência e Tecnologia e é investigador do

Centro de Estudos de Teatro da Faculdade de Letras da Universidade de Lisboa integrado no projecto OPSIS. Tendo já entregue a sua tese de doutoramento -

o Bairro Teatral portuense: 1850-1910 - aguarda a prova pública de Doutoramento em Estudos de Teatro na Faculdade de Letras da Universidade de Lisboa. 
cento e vinte e seis

Sinais de cena 20.2013 |

Arquivo Solto

Daniel Rosa

0 Bairro Teatral Portuense
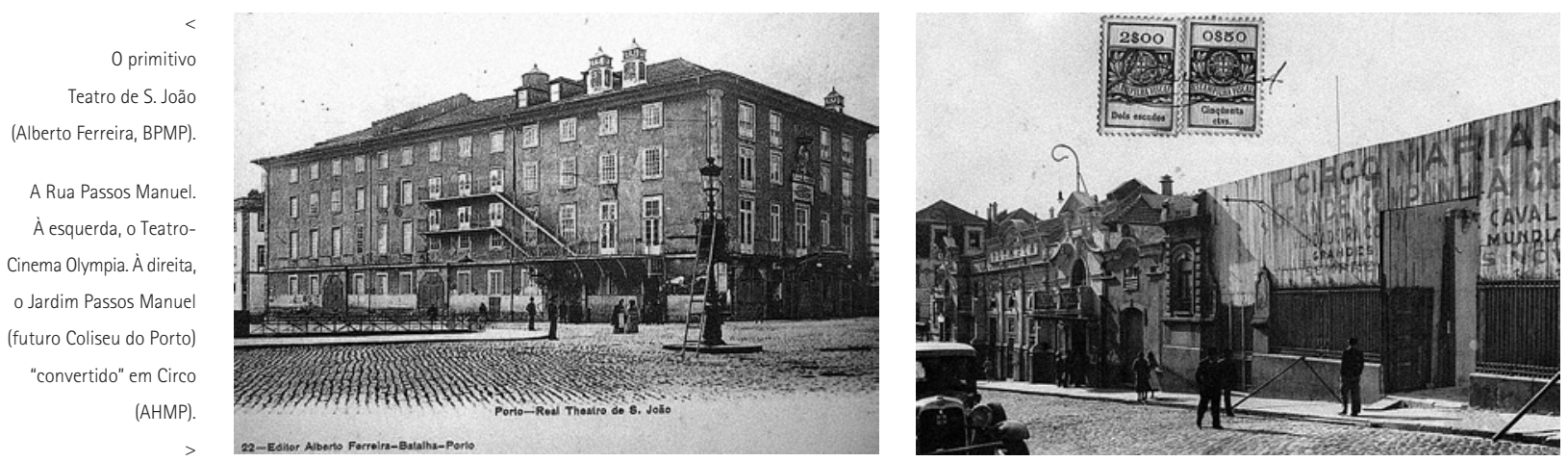

Vista da Rua Sá da

Bandeira. À direita, um

pormenor da fachada do

Teatro (BPMP).

0 Teatro Águia d'Ouro, à

Praça da Batalha (BPMP).

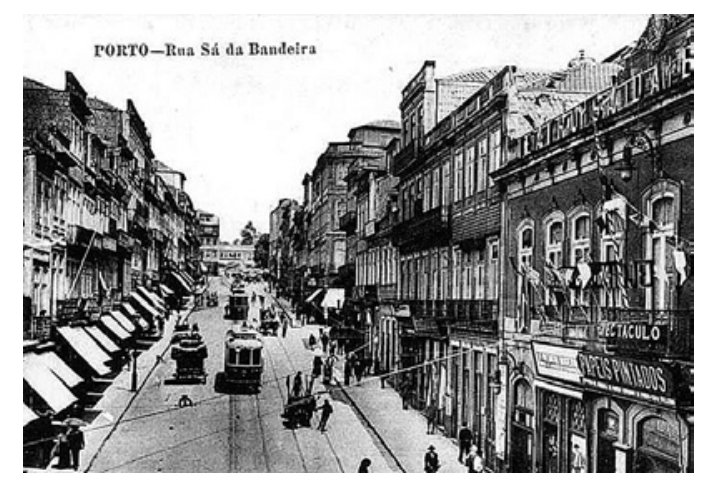

faziam, uns aos outros, vizinhos, coexistindo numa área urbana especifica. Era, assim, preciso um estudo urbano mas também sociológico e económico. Era, sobretudo, necessária uma metodologia que cruzasse diversas áreas do conhecimento, ainda que, por vezes, em algumas delas não nos sentíssemos confortáveis para tecer considerações. Mas era preciso esse atrevimento - ainda que moderado - de forma a desconstruir a nossa forma de pensar contemporânea, a do século XXI, e entrar no mundo oitocentista, absorvendo e assumindo os seus valores sociais. Mas primeiro havia que arrumar ideias.

A metodologia, essa, e como referido, foi previamente definida, pelos bons resultados obtidos a propósito da reconstrução histórica da identidade e atmosfera do Teatro Carlos Alberto. Em muitas obras bibliográficas, de menor pertinência mas de grande visibilidade, era recorrente repetirem-se impressões da época que não correspondiam totalmente à verdade, confirmando-o através da nossa pesquisa em periódicos. Para tal, estes diários da época seriam a nossa base, obviamente, sempre retirando a informação com cautela e espírito crítico. Era essa a nossa principal preocupação para que a nossa reconstituição histórica fosse o mais fiável possível: voltar aos arquivos e ir beber às fontes primárias, reinterpretando a história até aqui escrita. Recolhida esta informação, chegaria a altura de cruzar com a bibliografia sobre o tema. Esta decisão partiu não só das inconsistências verificadas em algumas obras mais ou menos recentes, mas da vontade em não nos deixarmos influenciar por outras formas de pensar. Obviamente que, por muito que desejasse manterme imparcial ao produzir conhecimento, a minha sempre será uma interpretação de factos históricos que não vivi. Afinal, seremos sempre indivíduos para quem, por muitos exercícios de distanciamento cultural que façamos, os valores da nossa época e o nosso olhar crítico estarão sempre no nosso subconsciente. Confortava-me, porém, saber que, regressando às que considerava as fontes

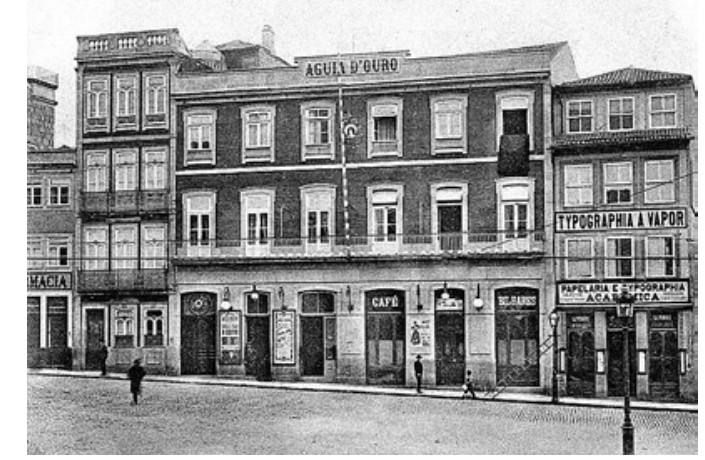

primárias para uma reconstituição da realidade teatral portuense entre oitocentos e novecentos, me depararia com menos filtros e camadas deixadas por outros autores.

Outro aspecto interessante, no que toca ainda à metodologia, foram os utensílios que usámos para nos transportarmos para a época e para vivê-la, ainda que apenas de olhos fechados: as obras de ficção contemporâneas do momento histórico que nos interessava caracterizar, ou, como quem diz a mesma coisa, os romances. $E$, sinceramente, foi um pouco ao acaso, pois tínhamos algures apontado que no romance de Júlio Dinis Uma familia inglesa, havia alguns episódios passados nos teatros oitocentistas. Apesar de consistirem em episódios ficcionados, achamos estimulante a forma como conseguimos sentir um pouco do que seria a atmosfera de um teatro da época e conviver, ainda que de uma forma muito indirecta, com o individuo que o frequentava. Entusiasmados pelas apraziveis tardes de leitura outras que nos permitissem conhecer nas só os teatros, mas o indivíduo da época, o que o movia, onde, algures na cidade, se divertia. E, felizmente, encontramos outro filão, desta volta de autores pouco conhecidos mas riquíssimos que nos davam a conhecer a cidade da época através das suas obras. João Grave e Lourenço Pinto, juntamente com as memórias de vários actores nacionais e estrangeiros que consultamos, foram confidentes de uma época que, graças à sua obra, passávamos a conhecer e compreender cada vez melhor.

Inicialmente, pensámos estudar um século inteiro mas rapidamente ficou claro que tal não seria possivel. Nem possivel, nem pertinente, pois muito ficaria por aprofundar. Havia sim que procurar um balizamento cronológico sensato e procurar responder às primeiras de muitas questões: onde, quando e porquê teve início esta fervorosa construção de edifícios devotos ao teatro, à volta dos quais gravitavam, como complemento à folia boémia, proporcionadas pela obra de Dinis, fomos à procura de 


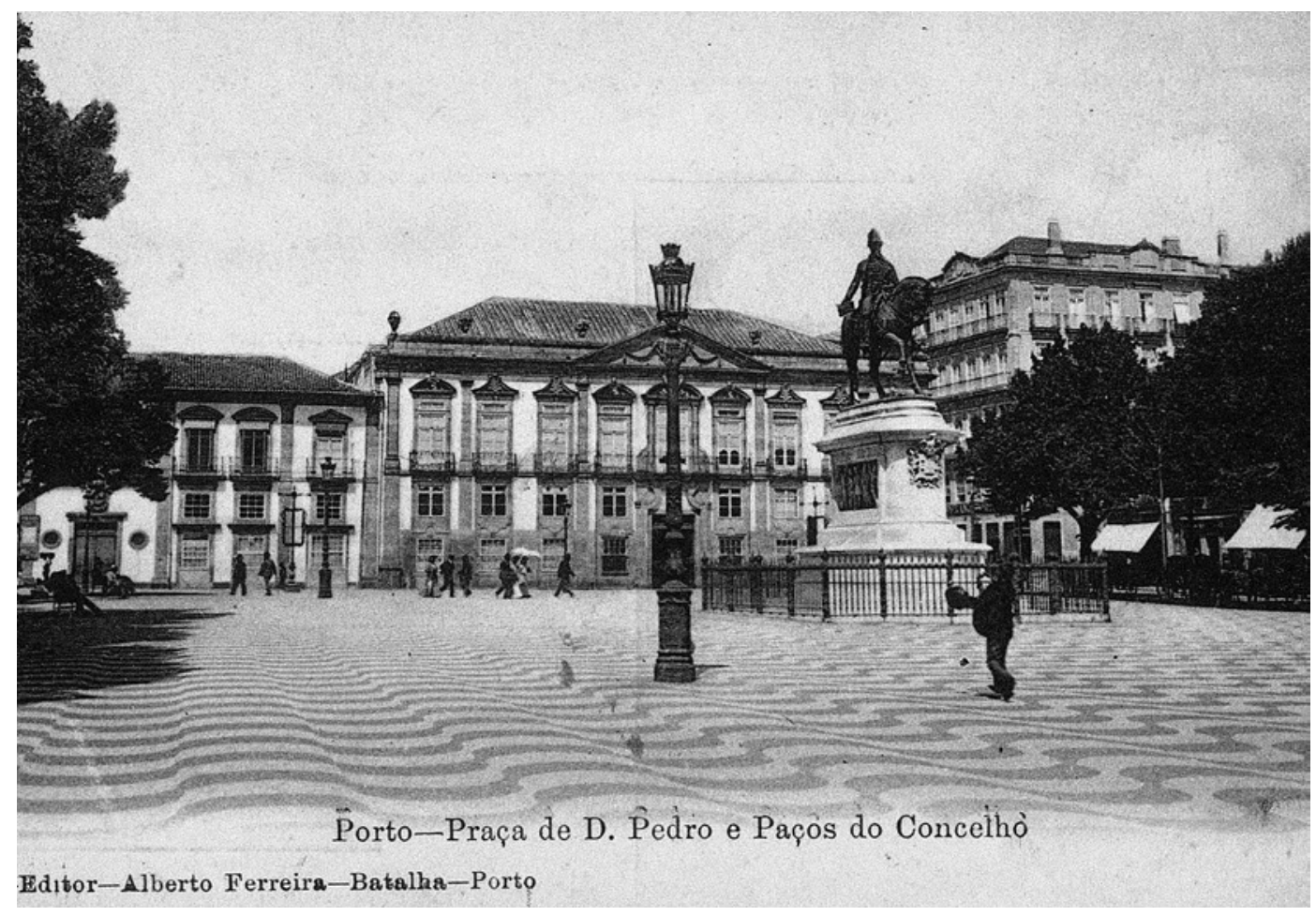

A Praça D. Pedro,

futura Praça da Liberdade (BPMP) outros equipamentos (cafés, salões de bailes...) que ritmavam a fervilhante sociabilidade do Porto de então? Já tínhamos algumas pistas, retiradas da obra de Luís Soares Carneiro, na qual encontramos o apoio e a inspiração necessária para acreditar que este tema de estudo merecia uma maior atenção. A sua obra, para os mais distraídos, proporciona um vastíssimo inventário sobre os teatros de raiz italiana em Portugal. Apesar da magnitude do estudo, sobretudo focado na análise arquitectónica desta tipologia de imóveis, havia a preocupação em perceber o seu enquadramento urbano, bem como a sua identidade programática. E era este o caminho que queríamos percorrer, ainda que de uma forma mais intensa. Se o estudo arquitectónico já se encontrava bem representado, faltava sentir o pulsar dos teatros e, sobretudo, da cidade que os vivia.

Só muito depois, percorridos muitos anos de periódicos, é que achamos viável estabelecer uma cronologia (quase) definitiva. Havia agora um princípio, um meio e um fim, sendo que este último era o terminar do nosso estudo mas, para a época, uma mudança de paradigma cultural, como explicaremos mais adiante. Assim, o início - e parte da resposta à nossa primeirissima questão - encontravase algures nos meados do século XIX. As datas sempre foram, é verdade, um dilema. Parecia-nos redutor - e errado - apontar uma data específica para o começo de uma actividade teatral significativa na cidade. Tudo era resultado de uma evolução mas, obviamente, não queriamos fazer uma história que tivesse que retroceder até aos tempos do Teatro do Corpo da Guarda e dos Celeiros da Cordoaria. Decidimos assim fazer a nossa proposta, através de balizamentos e datas, acreditamos nós, simbólicas. 0 início da segunda metade do século XIX correspondia a uma altura em que se chegava, finalmente, ao fim de uma instabilidade politica que se arrastava desde 1820, dando origem a um dinamismo económico e demográfico que terá impulsionado a edificação teatral, claros melhoramentos materiais ao serviço do divertimento de uma população agora com novos hábitos e possibilidades económicas. Era também o período em que o novo centro cívico, a Praça de D. Pedro, onde é actualmente a Praça da Liberdade, se havia finalmente afirmado e, à volta da qual, se iriam encontrar estes teatros, que aproveitariam os novos fluxos de sociabilidade que criara. A data simbólica escolhida foi 1854, ano da inauguração do Teatro-Circo, futuro Teatro Sá da Bandeira, e, a nosso ver, o começo de uma nova era na exploração teatral, encarada como um negócio, mais comercial e com uma oferta alargada às várias camadas sociais que agora podiam pagar um bilhete de teatro.

0 meio da narrativa trouxe outras preocupações que foram surgindo à medida que retirávamos dos periódicos cada vez mais informação inédita, ansiosa por que lhe dessem uso. Verificamos que cada teatro tinha a sua identidade e que se organizavam no espaço urbano, como aliás já foi dito, próximos uns dos outros. Chegamos assim à conclusão que existia uma rede teatral e uma espécie de conceito conhecido pelo nome de theatre district. A esse fenómeno, por diversas razões apontadas no nosso estudo - que esperamos vir a publicar - decidimos chamarIhe Bairro Teatral. Constatamos que, de facto, não havia uma concorrência significativa entre os vários teatros. De certa forma, cada um tinha a sua orientação programática e o seu público, e esta coexistência mais ou menos pacifica parecia resultar de uma permanente negociação entre os agentes teatrais, entre os quais, no topo da cadeia, estavam os empresários que arrendavam e exploravam os teatros. Os teatros ditos menores gravitariam à volta dos maiores, captando o mar de gente que deambulava neste recreio boémio que era o Bairro Teatral. Assim, e já conhecendo o futuro deste espaço urbano graças ao exaustivo levantamento realizado no decorrer do estágio, que nos levou até quase meados do século $X X$, chegamos ao meio do nosso estudo: a abertura da Rua de Sá da Bandeira, 
Pormenor da Praça da Batalha. À esquerda, o

Águia d'Ouro já

convertido em Cinema.

A direita, o local onde se viria a construir o Cinema

Batalha (AHMP).

0 Teatro Infante

D. Afonso, à Rua Alexandre Herculan

(AHMP). no início do último quartel de oitocentos. Se numa fase primitiva este Bairro Teatral era composto pela Praça D. Pedro, Rua de Santo António (actual 31 de Janeiro), Rua de Santa Catarina e Praça da Batalha (com uma possivel extensão até ao Jardim de S. Lázaro), no seu amadurecimento iria estender-se para a Rua Sá da Bandeira e, mais tarde, Passos Manuel, onde iriam surgir vários equipamentos destinados à arte cinematográfica, como o Teatro-Cinema Olimpia (o teatro que nunca foi teatro) - Salão-Jardim Passos Manuel ou, mais tarde, o Coliseu do Porto. Mas, essa, era outra realidade programática que em parte, determinou o fim do nosso estudo.

Tínhamos princípio e meio, faltava o fim. Este assumiria as datas simbólicas de 1908 e 1910, a primeira referindose ao ano em que o Teatro de S. João é consumido pelas chamas e uma nova realidade programática - a do Cinema - emergia, dominando, como já sabíamos à partida, as preferências do público, à qual os teatros não podiam deixar de responder. 1910 é, como se sabe, a data da implantação da 1a República. Era o fim ideal para o nosso estudo, apesar da nossa aversão aos balizamentos cronológicos. Já havíamos averiguado o que nos interessava: as motivações da organização de um theatre district no Porto, problemática que nos levou inclusive a viagens de estudo a Londres, procurando respostas e paralelismos no caso londrino e nova-iorquino; as tendências da nova sociabilidade ligada ao lazer; $e_{\text {, }}$ sobretudo, vivermos como espectadores da época, percebendo o que acontecia quando passadas as portas dos teatros. Mais: com o nosso estudo finalizado, acreditamos ter contribuido para que aqueles mais interessados (e entendidos) possam desdobrar as pistas deixadas. Fora essa outra das nossas grandes motivações: plantar uma árvore que desse frutos que todos pudessem colher para proveito próprio.

Percorrendo todos estes anos, e quem connosco o fizer, verá um Porto culturalmente global, a par do que acontecia "lá fora". De facto, o fenómeno do Bairro Teatral traduzido não literalmente mas simbolicamente do conceito urbano londrino e nova-iorquino do theatre district, parecenos ter sido isso mesmo: global. E se a articulação de casas de espectáculos e outros equipamentos sociais é extremamente semelhante em ambos casos, sente-se também na cidade - e muito graças aos teatros - uma globalização cultural, proporcionada pela vinda de grandes companhias estrangeiras (sobretudo italianas), que delineavam intermináveis tournées por esse mundo fora. 0 Porto, esse, após ganhar alguma reputação no meio teatral, no decorrer da segunda metade do século XIX muito graças ao mérito de alguns dos empresários que exploravam os seus teatros, conseguia trazer a esta cidade os artistas de renome sobre os quais todos liam e de que ouviam falar. Era um Porto que, desde o início da cronologia por nós proposta, se libertava progressivamente do rótulo provinciano e se inseria na rota das grandes companhias, servindo, igualmente, e juntamente com Lisboa, de cais
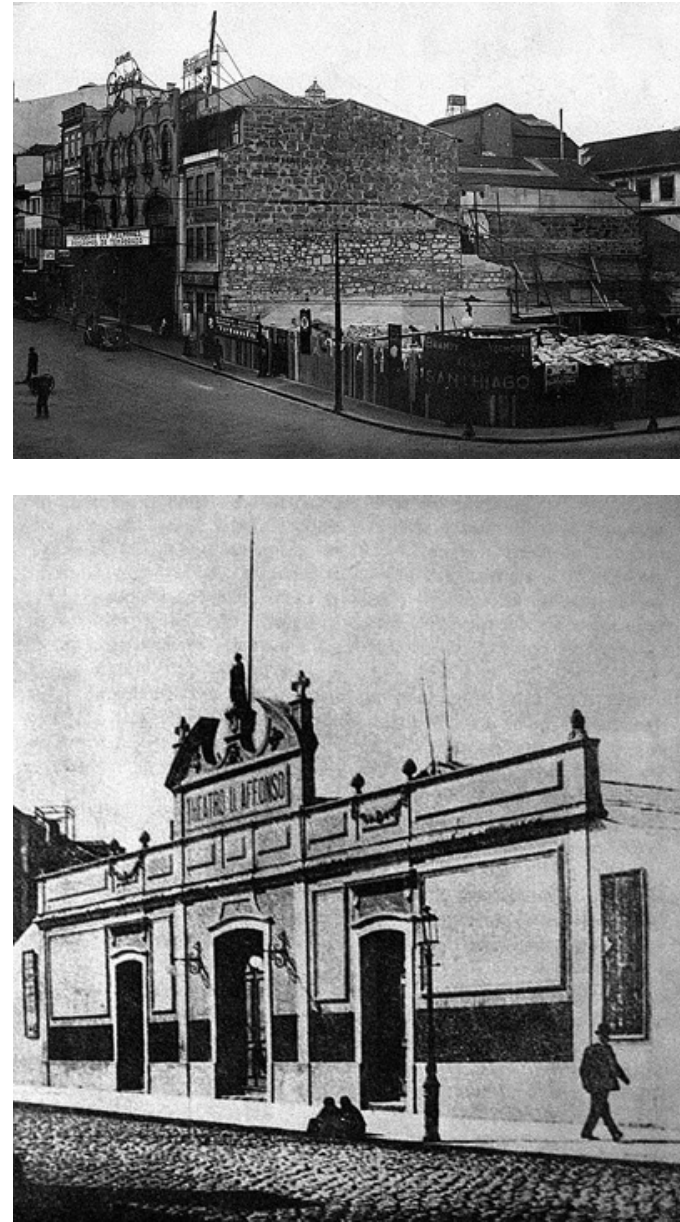

de entrada para algumas companhias estrangeiras, de teatro ou variedades, que depois das suas digressões por terras norte-americanas, se preparavam para conquistar os grandes palcos europeus.

Assim, a nossa dissertação é um convite ao leitor para um passeio - virtual - pela cidade, não daqueles passeios que duram um entardecer, mas um de aproximadamente 60 anos. Assim viverá como um portuense da época e vagueará pelo recreio boémio que era o Bairro Teatral. Será na parte alta da cidade, em detrimento da zona ribeirinha, que encontrará um novo centro de profusa sociabilidade, de discussão literária, política e mundana à sombra dos edifícios que enobreciam a central Praça D. Pedro ou na penumbra dos cafés que por ali iam despontando. Neste início da segunda metade do século XIX encontrará já alguns teatros que frequentar: o Teatro de $\mathrm{S}$. João, com as suas tempestuosas temporadas líricas e o acolhimento das mais conceituadas companhias dramáticas portuguesas, e o popular Teatro-Circo, que oferecia um teatro de fácil digestão e os sempre sedutores espectáculos de variedades. Em ambos se divertirá não só como espectador mas também como protagonista, participando na folia dos concorridissimos e excitantes bailes carnavalescos, imortalizados por Júlio Dinis. Ainda encontrará esporádicas representações dramáticas se estender o seu passeio à Rua de Santa Catarina, onde dará de caras com o teatro do mesmo nome, com alguns amadores a animá-lo. Mas muito terá com que ocupar o seu tempo de lazer: uma ida às touradas, às feiras recreativas ou um vagaroso passeio pelos novos jardins 


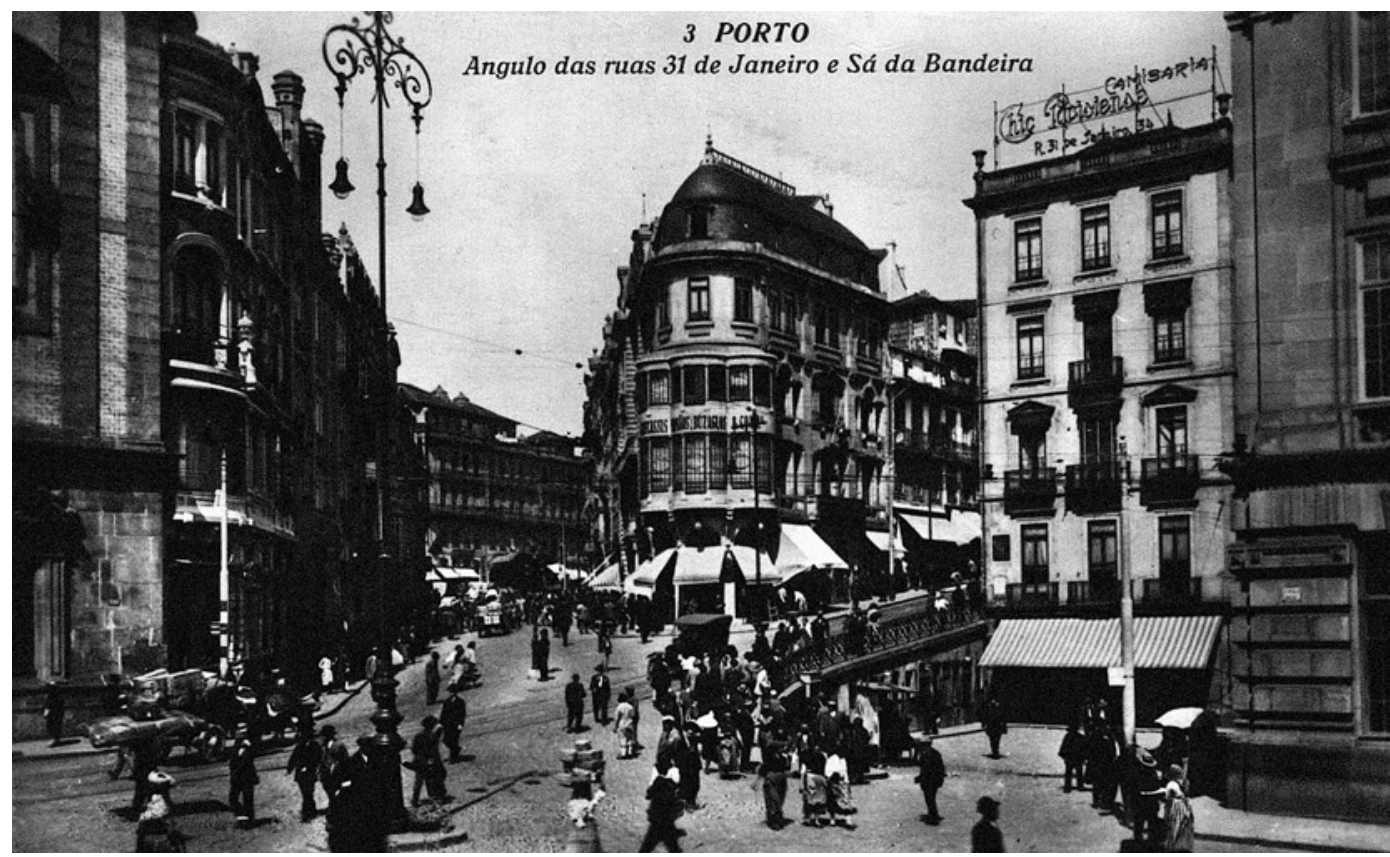

Ligação da Praça D. Pedro com as ruas Sá da Bandeira, à esquerda, e Santo António, à direita (BPMP).

da cidade, serão algumas das suas opções neste novo Porto que se transformava, não só urbana mas, sobretudo, social e culturalmente.

Mas é claro que a sua vontade será a de frequentar o Teatro de S. João, que tornou a Praça da Batalha o coração do Bairro teatral. 0 leitor quererá acudir, previamente aos espectáculos, à hospedaria Águia d'Ouro - futuro teatro -, mesmo ali na vizinhança do templo lírico. Nessas incursões a esta hospedaria, cruzava-se tanto com o comum portuense como com o abastado burguês, constatando que a verdadeira crítica teatral se fazia entre aquelas quatro paredes. Era nestes espaços que se orquestravam verdadeiros ataques ou elogios aos artistas que compunham as companhias líricas, normalmente gerando facções em prol de uma ou outra dama do lírico, que se desafiavam em pleno teatro. A verdadeira crítica, aquela capaz de derrubar um artista, uma companhia ou, até, um empresário, era a dos cafés e hospedarias da cidade que ecoava depois nos principais periódicos. A turbulenta ambiência destes espaços era transportada dali para os teatros e vice-versa, quando terminado o espectáculo.

Descendo a rua, a de Santo António (31 de Janeiro), reluzente pelas suas joalharias e modistas, poderá, em breve, escolher entre frequentar o Teatro do Príncipe Real (outrora Teatro-Circo) ou o novíssimo Teatro Baquet, que revolucionarão a actividade teatral da cidade. Neles encontrará um pouco de tudo, desde dramas a operetas ou zarzuelas, e até espectáculos de luta ou de companhias acrobáticas oriundas de meio mundo. Assistirá com impotência ao incêndio que fará desaparecer o Baquet, mas será confortado, poucos anos depois, pelo Teatro Águia d'Ouro, construído na, cada vez mais dinâmica culturalmente, Praça da Batalha. 0 Bairro teatral alargará um pouco mais as suas fronteiras e o leitor, feito espectador, encontrará um verdadeiro teatro popular: 0 Teatro D. Afonso, à Rua Alexandre Herculano, afluente da Praça da Batalha. Será este um importante equipamento cultural, pois a cidade havia ficado órfã de um teatro popular após as implacáveis vistorias - resultantes da tragédia do Baquet - que vitimaram os teatros-barraca dispostos um pouco por toda a cidade.

Era este Bairro teatral, este recreio que crescia e se articulava em prol do negócio, que víamos tornar-se no centro dos lazeres da população portuense, onde quem a ele afluia podia dar entrada num universo cultural que se havia globalizado graças às já referidas digressões das grandes companhias teatrais. Artistas de renome, primeiro a trágica Adelaide Ristori, mais tarde Sarah Bernhardt, Marcella Sembrich ou Ernesto Rossi, davam origem a verdadeiras procissões pela cidade, capazes de rivalizar com as entradas triunfais de alguns monarcas. A novidade acontecia ali, ao Bairro, e o Porto, com o aproximar do século XX, não só importa cultura - em forma de teatro - como a começa a exportar, sendo o caso mais sério a do empresário Afonso Taveira no Brasil. Portugal, teatralmente falando, já não era só Lisboa.

A efervescência durará até ao fatídico ano de 1908, altura em que um incêndio consome o Teatro de S. João. Ainda que havendo casas de espectáculos que,

modestamente, se ocupassem temporariamente das suas funções, a perda será grande e os esforços para o fazer renascer das cinzas envolverá toda a população. Porém, o portuense não prolongará por muito tempo esse luto. Havia muito a acontecer no Bairro e uma nova forma de entretenimento em particular começava a chamar a sua atenção: as sessões de cinematógrafo. Primeiro como complemento ao teatro, exibindo-se "fitas" nos intervalos das peças, enquanto se montavam os cenários, haviam de se tornar espectáculo independente, dominando boa parte da programação dos teatros existentes, começando igualmente a construir-se infraestruturas próprias, umas menos rudimentares que outras. Um caso de sucesso - e marcante, nesta mudança de paradigma programático é o Novo Salão High-Life, também ele construído no coração do Bairro teatral, ao qual se havia de juntar, logo de imediato, o Salão-Jardim Passos Manuel ou o TeatroCinema Olímpia. Aproximava-se a Era do Cinema e o Bairro estava, urbanamente, preparado para ela, pronto para a receber. Mas, essa, já é outra história. 


\section{$\mathrm{APCT}$ II, \\ Associação Portuguesa de Críticos de Teatro

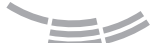

\begin{tabular}{l|l} 
Direcção & $\begin{array}{l}\text { Maria Helena Serôdio } \\
\text { João Carneiro } \\
\text { Rui Pina Coelho }\end{array}$
\end{tabular}

Assembleia Geral $\quad$ Alexandra Moreira da Silva Sebastiana Fadda

Conselho Fiscal Ana Isabel Vasconcelos

Mónica Guerreiro

Rita Martins

Capitulo Primeiro (Da Associação e dos seus fins)

ESTATUTOS $\quad$ Art. $2 .{ }^{\circ}$

A Associação tem por objectivo:

Dignificar, estruturar e responsabilizar a actividade crítica relativa à teoria e prática do teatro, entendendo-se por actividade crítica não só a crítica de espectáculos, mas também tudo aquilo que diga respeito à informação, reflexão e teorização no campo das artes performativas.

\section{Colaboração com Sinais de cena}

A revista está aberta à participação de quem deseje colaborar enviando artigos que julgue corresponderem aos objectivos da publicação e às modalidades enunciadas pelas rubricas existentes. A consulta do sítio da APCT na Internet (www.apcteatro.org) e o contacto por correio electrónico (estudos.teatro@fl.ul.pt) são indispensáveis para conhecer as normas de apresentação dos artigos (dimensão, aspecto gráfico, citações, referências bibliográficas, ilustrações, etc.).

\section{ASSINATURA}

Desejo subscrever os números 21 e 22 da revista Sinais de cena (correspondentes a Junho e Dezembro de 2014), no valor total de $22,00 €$ beneficiando assim de um desconto sobre o preço de venda ao público. Fora do pais: Europa $24,00 €$ / Fora da Europa $26,00 €$.

Nome:

Morada:

Código postal: Pais:

Endereço electrónico:

Forma de pagamento: Vale postal Cheque $n^{\circ}$. Banco (passar à ordem de Associação Portuguesa de Críticos de Teatro)

Preencha e envie este cupão (ou fotocópia do mesmo) para: Data: Sinais de cena Centro de Estudos de Teatro

Faculdade de Letras de Lisboa: sala 67 Alameda da Universidade 1600-214 Lisboa (Portugal) 